\title{
EGFR NP_005219.2:p.L861Q
}

National Cancer Institute

\section{Source}

National Cancer Institute. EGFR NP 005219.2:p.L861Q. NCI Thesaurus. Code C98497.

A change in the amino acid residue at position 861 in the epidermal growth factor receptor protein where leucine has been replaced by glutamine. 